\title{
A COMPARISON OF SCREENING TESTS FOR ANTI-SPERM ACTIVITY IN THE SERUM OF INFERTILE WOMEN
}

\author{
W. R. JONES, R. M. Y. ING AND M. D. KAYE \\ Department of Obstetrics and Gynaecology, University of Sydney, \\ Sydney, New South Wales, Australia
}

(Received 14th December 1971)

\begin{abstract}
Summary. Evidence of humoral anti-sperm activity was sought in the female partners of 196 couples with unexplained and organic infertility, and in a control group of fifty pregnant women. Two tests were used, sperm micro-agglutination and sperm immobilization. The microagglutination test demonstrated little difference in incidence of positive reactions in patients with unexplained and organic infertility and yielded an $18 \%$ incidence in the pregnant control patients.

The results of the sperm immobilization test showed a clear disparity in patients with unexplained infertility compared with those in the organic infertility and pregnancy groups. A comparison of these results with those obtained by other workers, using the same and other methods, suggests that the sperm immobilization test provides the most reliable single method for the detection of circulating anti-sperm activity with possible clinical significance.
\end{abstract}

\section{INTRODUCTION}

The immunogenicity of mammalian semen has been studied in a variety of experimental models over the past 80 years (Behrman, 1968; Shulman, 1971). Experimental autoimmune (male) and isoimmune (male and female) infertility can be induced in laboratory animals by immunization with seminal components, and this has established implications for spontaneous and induced infertility in man. This rapidly developing field has been the subject of several recent reviews (Katsh, 1967; Behrman, 1968; Edwards, 1970; Jones, 1971; Shulman, 1971).

Clinical interest in sperm isoimmunization as a possible cause of infertility was aroused by the early report from Franklin \& Dukes (1964) of spermagglutinating antibodies in the serum of women with otherwise unexplained inability to conceive. Since then, circulating anti-sperm antibodies have been detected by a variety of immunological techniques in both fertile and infertile women and this has led to confusion concerning their clinical significance.

This paper reports a comparison of two tests of humoral anti-sperm activity, sperm micro-agglutination and sperm immobilization, in the female partners of 
couples with unexplained and organic infertility, and in a control group of fertile women.

\section{MATERIALS AND METHODS}

A total of 196 infertile couples was investigated. Organic factors were demonstrable in forty-three of these, and the remaining 153 were categorized as having unexplained infertility, following routine investigations which included semen analysis, testing for tubal patency, endometrial biopsy and monitoring of the basal body temperature. Patients with organic factors were arbitrarily divided into two groups. The first included those with lesions closely related to the pathogenesis of infertility, such as tubal occlusion and endometriosis. The second comprised those with organic factors of lesser significance, such as oligomenorrhoea corrected by ovulation induction and incidental pelvic surgery. In the unexplained group, there were 111 couples in which the female partner had never become pregnant (primary infertility) and forty-two couples in which conception had occurred previously but in which secondary infertility of at least 2 years' duration had developed.

Patients attended the laboratory where blood was collected from both partners, and a fresh semen specimen was obtained from the male. Sera were incubated at $56^{\circ} \mathrm{C}$ for $30 \mathrm{~min}$ to inactivate complement. Semen specimens were examined immediately: those with sperm densities of less than $40 \times 10^{6} / \mathrm{ml}$ and with a sperm motility of less than $50 \%$ were considered unsuitable for testing.

\section{Sperm micro-agglutination test}

The method employed was that of Franklin \& Dukes (1964) as modified by Schwimmer, Ustay \& Behrman (1967a), using fresh semen from the male partner.

The specimens were prepared in serological tubes by adding $0.05 \mathrm{ml}$ semen to $0.5 \mathrm{ml}$ inactivated serum from the female partner. Semen was used in full strength, and in dilutions of $1: 5$ and $1: 10$ in Ringer's solution.

The tubes were incubated at $37^{\circ} \mathrm{C}$ and after $\frac{1}{2}, 1,2$ and $4 \mathrm{hr}$, one drop was removed from each tube by Pasteur pipette and examined under the microscope.

The type of agglutination (head-to-head, tail-to-tail, or mixed) was recorded and the degree of reaction was rated as follows:

$1+$ single agglutination (two or three spermatozoa) per several high power fields (HPF)

$2+$ single agglutination/HPF

$3+$ large aggregate/HPF

$4+$ several large aggregates/HPF

$5+$ massive agglutination.

Agglutination of motile spermatozoa was considered necessary for a positive reaction. The aggregation of dead spermatozoa, or of live spermatozoa and débris, was considered a non-specific reaction.

The test was recorded as positive if it was rated as $1+$ in at least two of the 
samples or if it was $2+$ or greater in one sample. It was found that agglutination was invariably of the head-to-head type.

\section{Sperm immobilization test}

The method used was that of Isojima, Li \& Ashitaka (1968). Inactivated serum $(0.25 \mathrm{ml})$ was added to fresh semen $(0.025 \mathrm{ml})$ and guinea-pig complement $(0.05 \mathrm{ml})$, and sperm motility was expressed as a percentage after incubation for $1 \mathrm{hr}$ at $37^{\circ} \mathrm{C}$.

Two tubes were used, the first (A) with the patient's serum and the second (B), a control with normal human serum. The ratio of $\%$ sperm motility in Tube $B$ to that in Tube A gave the sperm immobilization value (SIV). An SIV of 2.0 represented a $2: 1$ ratio of sperm motility in the presence of control serum compared to that in test serum. A value greater than this was considered a positive result.

A control test for non-specific sperm immobilizing activity involved the incubation of test serum with fresh semen in the absence of complement.

Serum from male partners was used in a proportion of these tests but it was found that the interpretation of results was difficult when initial sperm motility was less than $80 \%$. Accordingly, the use of semen from one of two donors of group $\mathrm{O}$ and containing at least $80 \%$ motile spermatozoa was used in all tests reported here.

\section{Control patients}

Fifty women in early pregnancy were utilized as a fertile control group and both tests were performed on their sera, using donor semen in each instance.

\section{RESULTS}

The results are summarized in Table 1 . The sperm micro-agglutination test was performed for all but three of the 196 couples studied; these were cases of organic infertility in which semen from the male partner was unsuitable for testing. The sperm immobilization test was performed for 181 couples including the three excluded from the micro-agglutination test. Insufficient serum was available from fifteen patients with unexplained infertility to permit testing for sperm immobilization.

There was only a small difference in incidence of positive sperm microagglutination in patients with unexplained infertility (both primary and secondary) and those with major organic infertility (Group A). The fertile control group also yielded a significant incidence of positive micro-agglutination tests.

The results of the sperm immobilization test showed a clear disparity in the patients with unexplained infertility compared with those in the major organic infertility and pregnancy groups.

A small number of couples were classified as infertile with minor or indeterminate organic factors (Table 1, Group B). The results in these, though included for completeness, are of uncertain significance.

A comparison of results from 178 couples in which both tests were employed 
failed to show a significant correlation between the tests. For 126 couples, both tests were negative; for forty-one, one was positive and the other negative; and for eleven, both were positive. It was noted, however, that when the immobilization test was positive, in only four instances was the micro-agglutination test negative, and for all seven couples with an SIV $>3 \cdot 0$, micro-agglutination was strongly positive.

Table 1. Results of sperm micro-agglutination and sperm immobilization tests

\begin{tabular}{|c|c|c|c|c|c|c|}
\hline \multirow{2}{*}{ Category } & \multicolumn{3}{|c|}{ Micro-agglutination } & \multicolumn{3}{|c|}{ Immobilization } \\
\hline & No. of patients & No.p & sitive $(\%)$ & No. of patients & No.p & sitive $(\%)$ \\
\hline $\begin{array}{l}\text { Primary unexplained } \\
\text { infertility }\end{array}$ & 111 & 29 & $(26 \cdot 6)$ & 101 & 12 & $(11 \cdot 9)$ \\
\hline $\begin{array}{l}\text { Secondary unexplained } \\
\text { infertility }\end{array}$ & 42 & 12 & $(28 \cdot 6)$ & 37 & 3 & $(8 \cdot 0)$ \\
\hline $\begin{array}{l}\text { Organic infertility* } \\
\text { A } \\
\text { B }\end{array}$ & $\begin{array}{l}28 \\
12\end{array}$ & $\begin{array}{l}6 \\
3\end{array}$ & $(21 \cdot 4)$ & $\begin{array}{l}29 \\
14\end{array}$ & $\begin{array}{l}0 \\
2\end{array}$ & $(0 \cdot 0)$ \\
\hline Pregnant & 50 & 9 & $(18 \cdot 0)$ & 50 & 0 & $(0.0)$ \\
\hline
\end{tabular}

* A: Patients with lesions closely related to the pathogenesis of infertility (e.g. tubal occlusion; endometriosis); B: Patients with organic factors of indeterminate significance (e.g. oligomenorrhoea corrected by ovulation induction; previous laparotomy and incidental pelvic surgery).

\section{DISGUSSION}

The genital tract in the female is well endowed with immunologically competent cells which presumably process seminal antigens and mediate local immune responses. It is well established that cervical mucus contains $\gamma$-globulins (Moghissi, Neuhaus \& Stevenson, 1960), and there is evidence (Hulka \& Omran, 1969) that these include immunoglobulins $\mathrm{G}$ and $\mathrm{A}$ (including secretory IgA). The human cervix contains cells capable of secreting IgA (Hulka \& Omran, 1969) and tissue antibodies have been demonstrated in the vagina, cervix and uterus of rodents (Paine \& Behrman, 1968) and humans (Schwimmer, Ustay \& Behrman, 1967b). Furthermore, Parish, Carron-Brown \& Richards (1967) have reported the presence of complement-fixing antibodies cytotoxic to spermatozoa in the cervical mucus of three out of forty-eight infertile women.

Clearly, immunological effector mechanisms must exist at a cellular and secretory level within the genital tract but their detection and quantification need further refinement. The sperm micro-agglutination test has been widely used as a simple screening test but our data and those of others (Table 2) demonstrate a perplexing variation in the incidence of positive results in both infertile and control subjects. The relevance of the micro-agglutination test to immunological infertility is further questioned by its poor specificity in experiments in vitro (Quinlivan, 1966; Israelstram, 1969), and by the demonstration that its activity lies in the $\beta$-globulin rather than the $\gamma$-globulin fraction of serum (Boettcher \& Kay, 1969).

Notwithstanding these findings, there was a notable association of strongly 
positive micro-agglutination with high SIV values in several instances of unexplained infertility in this study. It is difficult to exclude a possible influence in some of sperm-agglutinating activity in a non-immunological fraction of serum and genital-tract secretions, though this possibility is hard to sustain in the face of the reports of a poor correlation between positive sperm microagglutination and an abnormal post-coital test (Schwimmer et al., 1967a; Glass \& Vaidya, 1970).

Table 2. Incidence of positive sperm micro-agglutination tests in unexplained infertility

\begin{tabular}{|c|c|c|c|c|c|c|}
\hline \multirow[b]{2}{*}{ Author } & \multirow{2}{*}{$\begin{array}{l}\text { Infertility } \\
\text { category }\end{array}$} & \multirow{2}{*}{$\begin{array}{c}\text { No. of } \\
\text { patients studied }\end{array}$} & \multirow{2}{*}{$\begin{array}{c}\text { Positive tests } \\
\text { (incidence } \% \text { ) }\end{array}$} & \multicolumn{3}{|c|}{ Controls (incidence \%) } \\
\hline & & & & Fertile & Unmarried & $\begin{array}{c}\text { Organic } \\
\text { infertility }\end{array}$ \\
\hline Tyler et al. (1967) & Unstated & 43 & $14 \cdot 0$ & 0.0 & & \\
\hline$\underset{(1967 a)}{\text { Schwimmer et al. }}$ & $\begin{array}{l}\text { Primary } \\
\text { Secondary }\end{array}$ & $\begin{array}{l}64 \\
32\end{array}$ & $\begin{array}{l}37 \cdot 5 \\
50 \cdot 0\end{array}$ & $34 \cdot 1$ & $20 \cdot 0$ & $20 \cdot 0$ \\
\hline $\begin{array}{l}\text { Boettcher \& Hay } \\
\quad(1968)\end{array}$ & Unstated & 42 & $19 \cdot 0$ & & & \\
\hline Malinak et al. (1968) & Primary & 127 & $48 \cdot 0$ & $13 \cdot 0$ & & \\
\hline Israelstram (1969) & Unstated & 45 & $7 \cdot 0$ & & & \\
\hline Glass \& Vaidya (1970) & $\begin{array}{l}\text { Primary } \\
\text { Secondary }\end{array}$ & $\begin{array}{l}77 \\
45\end{array}$ & $\begin{array}{l}17 \cdot 0 \\
24 \cdot 0\end{array}$ & & & $4 \cdot 3$ \\
\hline Isojima (1972) & Unstated & 72 & $37 \cdot 5^{*}$ & $45 \cdot 8 *$ & $6 \cdot 3 *$ & $22 \cdot 4$ \\
\hline Present series & $\begin{array}{l}\text { Primary } \\
\text { Secondary }\end{array}$ & $\begin{array}{r}111 \\
42\end{array}$ & $\begin{array}{l}26 \cdot 6 \\
28 \cdot 6\end{array}$ & $18 \cdot 0$ & & $18 \cdot 0$ \\
\hline
\end{tabular}

Confusion also attends the results of a variety of other methods for the detection of humoral anti-sperm antibodies in infertile women (Table 3). This variation in incidence can, in part, be attributed to the multiple antigenantibody systems involved (Shulman, 1971), but the lack of clear discrimination in favour of unexplained infertility raises doubts concerning the clinical usefulness of these tests.

Our results with the sperm immobilization test confirm (Table 4) those of Isojima (1972). By contrast with other methods, the absence of positive reactions in the control groups suggests that sperm immobilization provides a reliable means of detecting humoral anti-sperm activity with possible clinical significance. This view is supported by fractionation studies of positive sera from women with unexplained infertility, in which the sperm immobilizing activity is evident in the IgG and IgM fractions (Isojima, 1972; Boettcher, 1972).

There is obviously a need for more complete information relating to the relative importance of seminal antigens, and to their specificity in the induction of immunological infertility. The recent demonstration of the presence of histocompatibility (HL-A) antigens on human spermatozoa (Fellous \& Dausset, 1970), foreshadows the application of more precise methodology to the investigation of sperm isoimmunization.

The present study is part of a project designed to establish the natural 


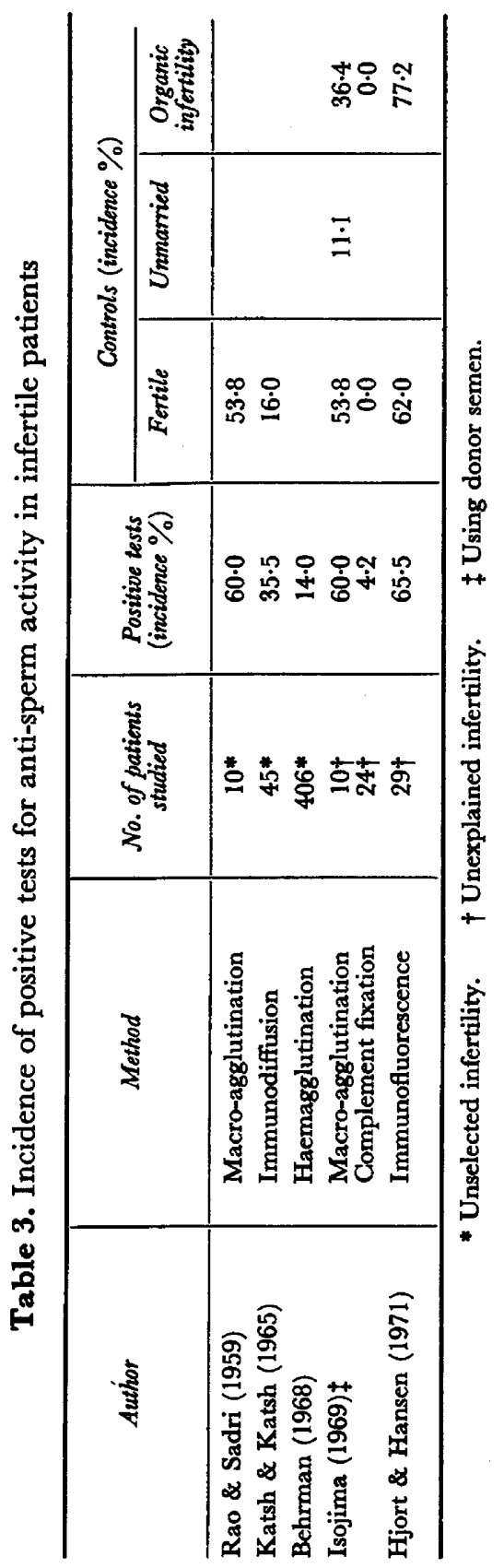


reproductive history of patients with circulating anti-sperm antibodies. It also aims to assess the outcome of a therapeutic approach to such patients, since early reports suggest that, if conversion to negative serological findings can be achieved by an occlusion regimen (male partner using condom), then significant pregnancy rates can be anticipated (Behrman, 1968; Glass \& Vaidya, 1970).

Table 4. Incidence of positive sperm immobilization tests in unexplained infertility*

\begin{tabular}{|c|c|c|c|c|c|c|}
\hline \multirow[b]{2}{*}{ Author } & \multirow{2}{*}{$\begin{array}{l}\text { Infertility } \\
\text { category }\end{array}$} & \multirow{2}{*}{$\begin{array}{c}\text { No. of } \\
\text { patients studied }\end{array}$} & \multirow{2}{*}{$\begin{array}{l}\text { Positive tests } \\
\text { (incidence } \% \text { ) }\end{array}$} & \multicolumn{3}{|c|}{ Controls (incidence \%) } \\
\hline & & & & Fertile & Unmarried & $\begin{array}{c}\text { Organic } \\
\text { infertility }\end{array}$ \\
\hline Isojima (1972) & Unstated & 74 & $17 \cdot 6$ & $0 \cdot 0$ & 0.0 & \\
\hline Present series & $\begin{array}{l}\text { Primary } \\
\text { Secondary }\end{array}$ & $\begin{array}{r}101 \\
37\end{array}$ & $\begin{array}{r}11 \cdot 9 \\
8 \cdot 0\end{array}$ & $0 \cdot 0$ & & 0.0 \\
\hline
\end{tabular}

\section{ACKNOWLEDGMENTS}

This work was supported by a grant from the Postgraduate Medical Foundation, University of Sydney. One of us (M.D.K.) has tenure of the Norman Haire Research Fellowship in the University of Sydney.

Patients investigated in this study were kindly referred by colleagues at King George V Memorial Hospital, Sydney.

\section{REFERENGES}

Benrman, S. J. (1968) The immune response and infertility. In: Progress in Infertility, p. 675. Eds. S. J. Behrman and R. W. Kistner. Little, Brown and Co., Boston.

Boetrcher, B. (1972) Fractionation of human sperm-agglutinating sera. In: Proceedings of the 2nd Int. Symposium on the Immunology of Reproduction. Varna, Bulgaria. (In press).

BoetTChER, B. \& HAY, J. (1968) An investigation of a proposed mechanism for infertility based on ABO blood group incompatibility, Am. J. Obstet. Gynec. 100, 437.

BoETtcher, B. \& KAY, D. J. (1969) Fractionation of a human sperm-agglutinating serum. Nature, Lond. 223, 737.

EDWARDs, R. G. (1970) Immunology of conception and pregnancy. Br. med. Bull. 26, 72.

Fellous, M. \& Dausset, J. (1970) Probable haploid expression of HL-A antigens on human spermatozoon. Nature, Lond. 225, 191.

Frankin, R. R. \& Dukes, G. D. (1964) Antispermatozoal antibody and unexplained infertility. Am. 7. Obstet. Gynec. 89, 6 .

Glass, R. H. \& VAWYA, R. A. (1970) Sperm-agglutinating antibodies in infertile women. Fert. Steril. 21,657 .

HJORT, T. \& HANSEN, K. B. (1971) Immunofluorescent studies on human spermatozoa. I. The detection of different spermatozoal antibodies and their occurrence in normal and infertile women. Clin. E exp. Immunol. 8, 9.

Hulka, J. F. \& Omran, K. F. (1969) The uterine cervix as a potential local antibody secretor. $A m$. 7. Obstet. Gynec. 104, 440.

IsojIMA, S. (1969) Relationship between antibodies to spermatozoa and sterility in females. In: Immunology and Reproduction, p. 267. Ed. R. G. Edwards. I.P.P.F., London.

Isojmi, S. (1972) Further studies of sperm immobilising antibody found in sera of unexplained sterile women. In: Proceedings of the 2nd Int. Symposium on the Immunology of Reproduction. Varna, Bulgaria. (In press).

IsojImA, S., LI, T. S. \& AshrTAKA, Y. (1968) Immunologic analysis of sperm-immobilising factor found in sera of women with unexplained sterility. Am. F. Obstet. Gynec. 101, 677. 
IsRaelstram, D. M. (1969) The presence of sperm agglutinating antibodies in the serum of infertile women. Fert. Steril. 20, 275.

Jones, W. R. (1971) Immunological aspects of fertility. Med. F. Aust. ii, 486.

KATSH, S. (1967) Immunologic aspects of infertility and conception control. In: Advances in Obstetrics and Gynaecology, p. 467. Eds. S. L. Marcus and C. C. Marcus. Williams \& Wilkins, Baltimore.

Katsh, S. K. \& Katsh, G. F. (1965) Perspectives in immunological control of reproduction: past, present and future. Pacific Med. Surg. 73, 28.

Malinak, L. R., MUmford, D. N. \& FrankLin, R. (1968) An expanded study of sperm agglutinating antibodies in fertile and infertile couples. Presented at the 24th Ann. Meeting of the American Fertility Society, San Francisco. Cited in Glass, R. H. \& Vaidya, R. A. (1970).

Moghissi, K., Neuhaus, O. W. \& Stevenson, C. S. (1960) Composition and properties of human cervical mucus. I. Electrophoretic separation and identification of proteins. F. clin. Invest. 39, 1358.

Patne, P. J. \& Behrman, S. J. (1968) Antibody localisation in guinea pig reproductive tissues. Int. $\mathcal{F}$. Fert. 13, 121.

Parish, W. E., Garron-Brown, J. A. \& Richards, C. B. (1967) The detection of antibodies to spermatozoa and to blood group antigens in cervical mucus. F. Reprod. Fert. 13, 469.

Quintrvan, W. L. G. (1966) Antigen-antibody reactions with human semen. Fert. Steril. 17, 722.

RAO, S. S. \& SADRI, K. K. (1959) Immunological studies with human semen and cervical mucus. In: Proc. VIth Int. Congr. Planned Parenthood, New Delhi.

Schwimmer, W. B., Ustay, K. A. \& Behrman, S. J. (1967a) An evaluation of immunologic factors of infertility. Fert. Steril. 18, 167.

Schwmmer, W. B., Ustay, K. A. \& Behrman, S. J. (1967b) Sperm-agglutinating antibodies and decreased fertility in prostitutes. Obstet. Gynec., N.Y. 20, 192.

Shulman, S. (1971) Antigenicity and auto-immunity in sexual reproduction. A review. Clin. $\mathcal{E}$ exp. Immunol. 9, 267.

Tyler, A., Tyler, E. T. \& Denny, P. G. (1967) Concepts and experiments in immunoreproduction. Fert. Steril. 18, 153. 